\title{
Controlling inventories in a supply chain: a case study
}

\author{
Eric Porras Musalem, Rommert Dekker \\ Erasmus University of Rotterdam
}

Econometric Institute Report EI 2002-53

\begin{abstract}
This article studies specific aspects of the joint replenishment problem in a real supply chain setting. Particularly we analyze the effect on inventory performance of having minimum order quantities for the different products in the joint order, given a complex transportation cost structure. The policies suggested have been tes ted in a simulation model with real data.
\end{abstract}

Keywords: Inventory, joint replenishment, minimum order quantities, supply chain management

\section{Introduction}

One of the most important aspects affecting the performance of a given supply chain is the management of inventories, since the decisions taken in this respect have a significant impact on material flow time, throughput and availability of product. Particularly interesting and very often found in real supply chains, is the problem of coordination in the replenishment of multiple products when they share common resources (i.e. same mode of transportation or same stocking location), with the idea of benefiting from the savings in fixed costs. Special attention has been turned to this problem in the literature for the last three decades. Nevertheless, few studies relate the mathematical models so far developed with real supply chains or inventory applications. Most of the models encountered in the literature for the joint replenishment problem are based on assumptions that do not always hold in real settings. For instance they ask for the specification of minor set-up cost for the replenishment of an item, i.e., fixed costs associated with each particular product, which for real supply chains are difficult to estimate.

In consequence, the objective of this article is to study the impact of joint replenishment policies in a real supply chain, and the effect of non-linear transportation costs. We investigate how inventory performance is affected by minimum order quantities for the individual items. Classical theoretical models overlook this important aspect.

In the next section we describe the case study. Section 3 presents a literature review on joint replenishment. Section 4 describes the simulation model and its main assumptions. In section 5 we discuss the results of the experiments carried out with the simulation tool. Sections 6 presents analytical considerations using the EOQ procedure, and the final conclusions are presented in section 7. 


\section{Case study}

\section{The company}

We consider a start-up company that commercializes gift items in The Netherlands and Belgium. The company orders the items from a manufacturer located in China, who in turn receives raw material and components from a variety of suppliers (see product description). The company keeps inventory of items at a Distribution Center (DC) in The Netherlands by means of a Vendor-Managed Inventory contract with the distributor, who is responsible of sending out the items to the final retailers. The items are shipped to The Netherlands by container (either full container or less-than-a-full container) and once in the port of Rotterdam a third party trucking company brings the items to the DC.

\section{The product}

The items are produced in 23 different types and consist of a chip (which contains a music song) and other components. The items are homogeneous for transportation. The minimum order quantity for a specific chip is 10,000. There are eight different chips, each of them containing one specific song. Each chip is used in a family of different items (see table 2 in section 4). The manufacturing process for the chips comprises two steps, namely the masking of the chip, which needs to be done only once, and the production process itself. Once the chip has been masked its production time is 20 days.

\section{Lead times}

Other lead times are as follows: the time to assemble the items is 14 days and transportation from China to the port of Rotterdam adds another 18-22 days. Finally, 3 to 5 days are needed to take the items from Rotterdam to the DC. Thus, we have a maximum total lead time for the items of 61 days (all days considered are calendar days). Shipping the items by air would reduce the lead time considerably, but due to the high costs associated it is not considered as an option. There is, however, another way for the company to reduce the total lead time by keeping inventories of certain subassemblies in order to speed up the production process. We consider this option to reduce the total lead time to 39 days.

\section{Stock control}

In the retail stores a rack with 20 different gift items with 5 copies of each is displayed. During the week, the distributor checks the inventory of items at the stores. In case of stockouts or low stocks it replenishes the racks with available inventory from the DC. Since not all the 23 different items can be displayed in any particular rack, they are evenly distributed among the stores, in order to have all items selling to final customers. Stockouts may occur but since no track of backorders is kept at the selling points we have no form of evaluating stockout costs, also because substitution of items may occur in such case. Therefore, we consider a lost sales inventory system. The only report about the inventory status is generated at the DC according to the stock policy of the distributor described above. This is the only source of demand information. Accordingly, we are interested in the customer service level only at this point of the supply chain, measured as the ready rate, which can be translated into a fill rate by assuming a constant demand rate at the DC. 


\section{Problem definition}

The main problem is to coordinate the replenishment of orders for groups or chipfamilies of items while keeping total costs low (transportation and holding costs) and achieving a certain customer service level at the DC. The main constraints are specified minimum order quantities for the production of families of items at the assembly plant due to the chip lot sizes, and different shipment sizes due to the use of half or full containers for transporting the items from China to The Netherlands.

\section{Cost structure}

\section{Transportation costs}

We can identify two main components in the transportation cost for the items: the shipping cost from China to Rotterdam (R'dam) and the cost associated with the handling of the items from the time they reached the port of R'dam until they finally arrive at the DC (including the transportation cost form R'dam to the DC). Thus, the first component represents the sea transportation cost and is included in the cost of the items, since the manufacturer charges this cost free on board (FOB) in Rotterdam, provided that a minimum order quantity is ensured by the company. Accordingly, if a replenishment order is between 45,000 and 52,000 items a full container is used and the manufacturer charges 1.25 USD per item (we use a conversion rate of 1 USD $=1$ euro). If the company decides to order less than 45,000 items, a less-than-a-full container (LFC) is sent and the price charged by the manufacturer is 1,27 USD per item. No shipments with less than 10,000 items is allowed. In consequence, we include in the transportation cost a penalty cost of 0,02 USD per item for not using a full container.

The second component is our real set-up cost, and is incurred by the company in any replenishment occasion once a shipment arrives in the port of R'dam, according to the following:

If a full container arrives the associated cost is 700 euros, which includes the handling container-related cost and the transportation from the port of R'dam to the DC. For orders which contains less than 45,000 items the cost associated with a LFC is given by:

Cost of handling and transportation for $\operatorname{LFC}=(210+y)+5.45 x$ euros

where $x$ is the total number of items (in thousands) in the shipment and $y$ is given by the following rule:

$$
y=\left\{\begin{array}{cll}
80 & \text { if } & 10 \leq x<15 \\
100 & \text { if } & 15 \leq x<20 \\
140 & \text { if } & 20 \leq x<25 \\
170 & \text { if } & 25 \leq x<30 \\
200 & \text { if } & 30 \leq x<35 \\
230 & \text { if } & 35 \leq x<40 \\
240 \text { if } & 40 \leq x<45
\end{array}\right.
$$


Note: If more than one container is needed, then always one will be full and the total cost will be the sum of the costs associated with the container sizes involved in the shipment according to the rules previously presented.

Set-up costs were not identified and not charged.

Holding costs

As a consequence of keeping stock of items at the DC, the company incurs a holding cost which includes the storage cost and the cost of capital invested in inventory. Of the two components, the latter is the most important, since the money borrowed by the company for working capital has a high risk due to the fact that the company is starting to be positioned in the market. We use an annual holding cost rate of $25 \%$.

An inventory of chips may be held at the assembly plant. In that case the company will have a VMI contract with the manufacturer with two main advantages: the reduction of the total lead time for the production process and the relaxation of the minimum order quantities for the items. The holding cost for the company in this case is only the cost of capital tied up in inventory, which is $20 \%$ annually. The cost of the chips is as follows:

Orders from 10,000 to 40,000 chips:

0.400 USD per chip

From 50,000 chips on:

0.375 USD per chip

Administration related costs are negligible compared with transportation or holding costs, so for the sake of simplicity we don't take them into account.

\section{Demand data}

When dealing with joint replenishment one of the important aspects to consider is whether the different products are homogeneous in terms of demand. We performed an analysis of demand data for individual items to evaluate the differences between items and to check whether it was possible to group them according to their demand rates.

We consider the demand generated at the DC as real demand. We classified the items according to their demand rates in fast movers (FM), medium-high movers (MHM), medium-low movers (MLM) and slow movers (SM). These four categories were clearly identified from the histogram of the demand distribution. Moreover, no seasonal patterns or correlations were detected for the demand of items. Although one could not really expect that demand would behave stationary, we did not have indications to model that explicitly. We performed a normality test for the aggregated demand in the categories to see whether this could be a reasonable assumption for the demand of items in our simulation model. The null hypothesis of normality was not rejected at $5 \%$ significance level with a p-value of 0.20 . We established a weekly total average demand of 2,942 items and we found an empirical ratio for the 4 categories of items of 3.1:2.5:1.8:1 (FM:MHM:MLM:SM). The demand rates for the four categories are shown in Table 1, where the C.V. (coefficient of variation) is also reported (see table 2 in section 4 for composition of families). 
Table 1

$\begin{array}{lc}\text { Category } & \begin{array}{c}\text { Average weekly } \\ \text { demand per item }\end{array} \\ \text { FM (4 items) } & 202 \\ \text { MHM (4 items) } & 166 \\ \text { MLM (7 items) } & 121 \\ \text { SM (8 items) } & 65\end{array}$

$\begin{array}{cc}\begin{array}{l}\text { Weekly standard } \\ \text { deviation per item }\end{array} & C . V . \\ 131 & \\ 106 & 0.649 \\ 83 & 0.638 \\ 44 & 0.686 \\ & 0.677\end{array}$

\section{Literature Review}

Inventory models found in papers related to the JRP literature basically fall in two main categories according to the nature of demand: deterministic and stochastic models. In the deterministic methods it is assumed that the major ordering cost is charged at a basic cycle time $T$ and that the ordering cycle of each item is some integer $k_{j}$ multiple of $T$, which is called a $\left(k_{j}, T\right)$ policy. In this line of research Goyal [4] proposed a solution method for the JRP based on enumeration, and therefore only suitable for small instances of the size problem. Moreover, he did not specify bounds for the problem and therefore one cannot test for optimality. Wildeman et al. [11] presented a more suitable optimal solution method for larger problems based on Lipschitz optimisation. Other authors focused on heuristic procedures. All of the methods suggested by these authors ask for the allocation of minor set up costs, which in our case were not present. Another important short coming of these methods is the treatment of the major ordering cost, which is often presented as a constant cost regardless of the number of items included in the order.

In the stochastic arena, Balintfy [2] first introduced the use of $(S, c, s)$ systems or "canorder" systems, in which items are replenished up to level $S$ if they reach a reorder level $s$. Coordination is achieved by including in the order any other item of the same family whose inventory level is below its can order level $c$. Later, Silver [7] proposed a method to determine in an optimal way the parameters of the $(S, c, s)$ system. Although this policy performs relatively well, Ignall [5] showed that optimality cannot be guaranteed. Alternatively to $(S, c, s)$ systems, for which a continuous review policy is needed, Atkins and Iyogun [1] proposed the use of periodic replenishment policies, where all items or specific subsets of them are ordered in every replenishment opportunity up to a base stock level $S$. Here the objective is to select optimal values of the review time and the order up to level $S$. Eynan and Kropp [3] presented an algorithm to find optimal values of the review time under stochastic demands using firstly a single item model and then extending it to the multi-item case. Although this algorithm could be used in real applications, the authors don't consider a complex structure of the fixed cost.

Viswanathan \& Piplani [10] and Ramirez \& Espinosa [6] discuss some real applications of coordination, by means of quantity discounts and capacity constraints in transportation. However, they do not consider minimum order quantities or a staircase transportation cost function. 
The methods found in the JRP literature are important from a theoretical perspective. Few studies of the joint replenishment problem have been related to real supply chains, and to the best of our knowledge there are no methods available in the literature when minimum order quantities are a restriction of the system.

\section{Simulation model}

A simulation model was built to analyze the problem in which the net inventory and inventory position are controlled individually for each item with a time step of one week. Demands not met from stock are lost. The demand of each item is considered normally distributed with parameters given in table 1. For demands with large value of C.V. we cut off the negative part of the left tail of the normal distribution by setting to zero all negative demands, which caused only a marginal distortion. In table 2 we present the families of items considered in the simulation model.

Table 2. Families of items

$\begin{array}{lcccc}\begin{array}{l}\text { Family } \\ \text { (chip \#) }\end{array} & \text { FM } & \begin{array}{l}\text { Type of item } \\ \text { MHM }\end{array} & \text { MLM } & \text { SM } \\ & & 6 & 14 & 23 \\ \text { IC 1 } & 7 & & 20 & 15 \\ \text { IC 2 } & 8 & & 16 & 13,15,22 \\ \text { IC 3 } & & & & \\ \text { IC } 4 & 11 & 3,19 & 4,12,21 \\ \text { IC 5 } & & 17 & 9 & \\ \text { IC 6 } & 1 & 10 & 18 & \\ \text { IC 7 } & 2 & & \end{array}$

Two inventory policies are considered, according to the following:

Case 1. $\left(k_{j}, T\right)$ joint replenishment with minimum order quantities for the chips.

(a) The system is controlled at chip level, using feasible subsets of chips for the joint replenishment. We consider a base replenishment time of $T$ weeks and a frequency factor $k_{j}$ for chip $j$. The quantities ordered for the families of items have to satisfy the minimum order quantity for the chip and the lot sizes for individual items are determined by ensuring an equal number of days in stock according to average demand. This is done in the following way: we search for $k_{j}$ and $T$ such that the service level is at least $90 \%$. Due to the discrete nature of demand, we applied enumeration instead of continuous optimization to determine optimal policy parameters. What follows is the detail description of the algorithm considered.

STEP 0. Select an appropriated set of values of the frequencies $k_{j}$, using the following initial criterion: Set $k_{j}=1$ for the family with the highest rate of average demand, $k_{j}=$ 2 for the family with the second higher rate of average demand and so on. Define $A d d Q_{j}$ as an additional quantity of chip $j$ and set its value initially equal to zero. 
STEP 1. For each selected set of values of the $k_{j}$ run the simulation using different values of $T$, starting with a value of one week and then increasing its value in steps of one week. Order the following quantity for item $i$ inside family $j$ (or equivalent containing chip $j$ ):

$Q_{i j}=\left(M O Q+A d d Q_{j}\right) w_{i j}$

where $M O Q$ is the minimum order quantity per family and the weights $w_{i j}$ are evaluated according to average demand as follows:

$w_{i j}=\frac{\bar{D}_{i j}}{\bar{D}_{A, j}} \quad$ and $\quad \sum_{i} w_{i j}=1 \quad$ for all chip $j$

where $\bar{D}_{i j}$ is the weekly accumulated average demand of item $i$ inside family $j$, and $\bar{D}_{A, j}$ is the weekly aggregated average demand of family $j$.

STEP 2. For each run of the simulation model evaluate the average annual transportation cost using the cost structure presented in section 2 , and the average annual holding cost of the system. Compute for each item $i$ inside family $j$ the $\%$ of time that the net inventory is zero. Compute the $\%$ of time that the net inventory of the system (all families) is zero by averaging values for each family.

STEP 3. For all values of $T$ for which the $\%$ of time that the net inventory of the system is zero is less than $10 \%^{1}$, compute the total average costs as the sum of the average transportation cost and the average holding cost.

STEP 4. Select new values of the $k_{j}$ using the following general rule: families with higher rates of demand will have lower values of $k_{j}$ and families with lower rates of demand will have higher values of the $k_{j}$.

STEP 5. Repeat steps 1 through 4 trying for different values of $A d d Q_{j}$, according to the following rule: for each family whose maximum $\%$ of time out of stock over all items inside that family at the end of the simulation run is higher than $10 \%$, increase $A d d Q_{j}$ in steps of 500 chips (the minimum number allowed for a set of production in the masking process) until an acceptable value of the $\%$ of time out of stock is reached.

STEP 6. Select the best values of the $k_{j}$ and $T$ for which the average total cost is the lowest of all trials.

(b) Same considerations as in part (a) but with pre-determined sizes of container to be used in the replenishments. This set of experiments is motivated by the idea that using the algorithm presented in part (a) we could get a solution in which different sizes of containers are used in every replenishment opportunity, which from the point of view

\footnotetext{
${ }^{1}$ We set the value of $10 \%$ according to the customer service level required at the DC as an equivalent measure of the fill rate.
} 
of transportation efficiency is not optimal. We define the following structure of experiments:

A. Experiments using only one specific size of container (see table 2):

FC: Full container (45,000-52,000). Includes: FC1, FC2, FC3 and FC4.

LFC40: Less-than-a-full-container with 40,000 items.

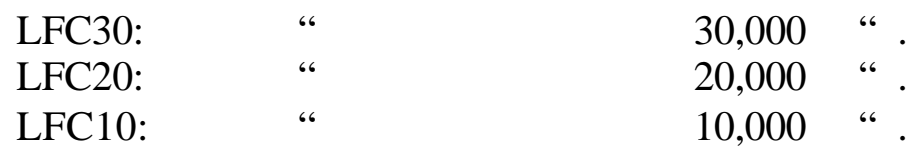

B. Experiments with containers of different sizes (Table 3).

The choice made for the container sizes is based on proper combinations of containers that allow to distribute the families in the different replenishments according to their average rate of demand in order to better control the stockouts and to keep inventory levels not too high, and at the same time on the efficient use of the transportation system. We consider the following experiments: (as before, the letters indicate the type of container followed by the number in thousands of the units it contains)

(FC50+LFC30). Full container plus one LFC in every replenishment. We send always a coordinated replenishment of all items, and we exploit the advantages of using always a full container.

(FC50, LFC30, LFC30). Full container and two LFC's sent alternately. The use of the LFC allow us to better match supply with demand of the families with low rates of demand, namely for chips 4 and 6. On the other hand we exploit the advantage of using a full container in every three replenishments.

(FC50, LFC30). In this experiment we try to reduce the \% time out of stock for chips 4 and 6 by sending them in every two replenishment and at the same time still exploiting the full container economical advantage.

(LFC30, LFC30, LFC20). We sacrifice the use of full container for using only LFC's that better allow us to distribute the items according to their rates of demand.

(FC50, LFC30, LFC45). We exploit economies of scale offered by the use of full container but to use it alternately with LFC to better match supply and demand for the fast and slow movers.

Case 2. Joint replenishment with no constraint of minimum order quantities for the chips, because of keeping stock of chips at the assembly plant, but with a minimum order quantity for the total replenishment lot size (container constraint).

The system is controlled using an order-up-to-level inventory policy considering a customer service level to be guaranteed at the DC. We compare the performance of the system using the following two control policies:

a) $(T, S)$, b) $(T, s, S)$. 
In case (a) the system is reviewed every $T$ time units. The lot sizes for the individual items are evaluated according to the order-up-to-level $S_{i}$ of each item. The replenishment will be effective only if the total replenishment size is at least equal to the minimum order quantity required by the container. Using the simulation we search for the best values of the parameters $T$ and $S$ that gives the minimum annual total cost, given $10 \%$ as the maximum allowable percentage of time that the system is out of stock (the same customer service level used in case 1). One way to choose the orderup-to-level $S_{i}$ for item $i$ is to relate its value to the average demand of the item during the review time $T$ plus the lead time. Accordingly, we start out our search of the parameter $S_{i}$ by initially setting its value using the following equation:

$$
S_{i}=D_{i}(T+L)+z \sigma_{i} \sqrt{T+L}
$$

where $D_{i}$ and $s_{i}$ are the annual average demand and standard deviation of item $i, L$ is the total lead time, and $z$ is a multiplier of $s$ that determines the cycle service level.

We run the simulation for the $(T, S)$ policy using the same cost structure as the one in case 1 , namely the transportation cost structure presented in section 2 . We search for the best value of $S_{i}$ by varying the value of $z$.

In case (b) the coordination is performed using the following strategy: the inventory position of each item inside its family is checked with a constant review time $T$ equal for all items. When the inventory position of an item drops below its reorder point $s_{i}$, it triggers the replenishment order for the family to which it belongs. The lot sizes for the items inside the family are evaluated again according to the order-up-to-level $S_{i}$ of each item and the replenishment is finally effective only if the minimum order quantity for the container is satisfied. We look for the best possible values of the parameters $T, s$ and $S$ by trying different values and computing total average annual cost.

Whichever policy is used, every time a replenishment of items is ordered, the system incurs a transportation cost according to the underlying cost structure. After a constant lead time, the replenishment arrives to the system and the status of all inventories is updated. The simulation model evaluates the holding cost associated with the average inventory held per year at the DC plus the holding cost associated with the average number of chips in stock at the assembly plant. To keep things not too complex in the simulation model, we do not keep track of the inventory of chips, we rather calculate the average stock directly while assuming an initial value of 25,000 chips.

\section{Experiments and discussion of results}

Case $1(a)$. No intermediate stocks. MOQ for the chips. Experiment with free values of $k_{j}$ (see Table 1)

We vary the review time $T$ and evaluate for each value the following:

- Average total cost of the system per year = Average annual transportation cost + Average annual holding cost

- Average \% time out of stock over all items 
Summary of simulation results

Table 1. Experiments varying frequencies $\mathbf{k j}$

Definition of experiments

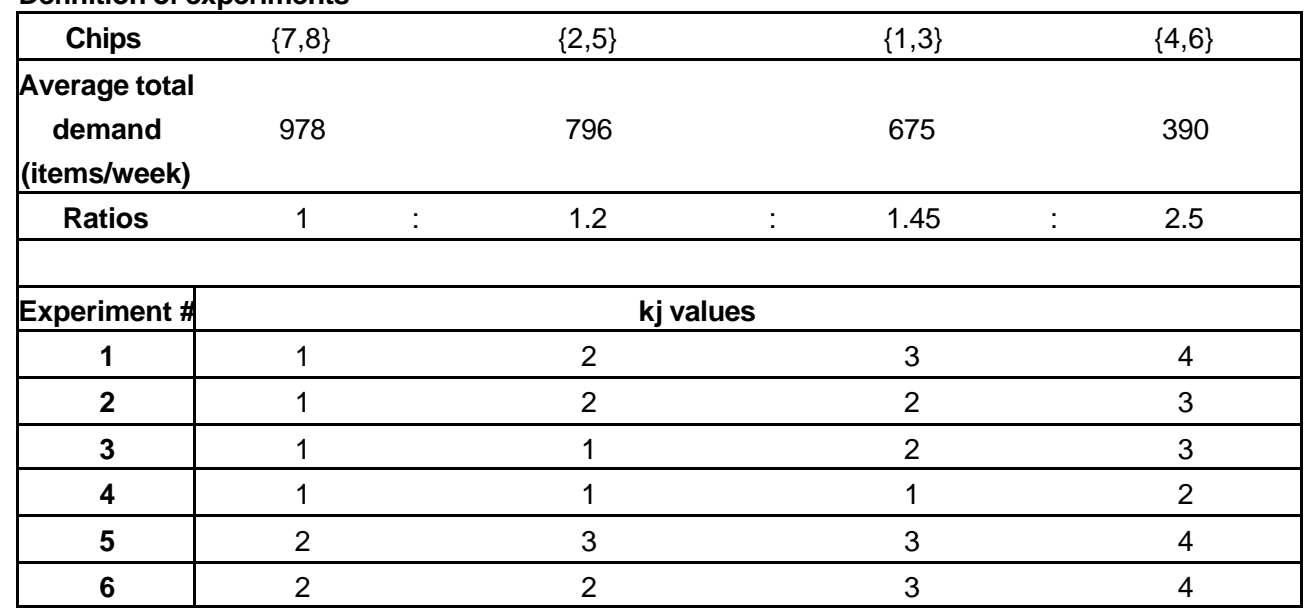

\section{Results}

\begin{tabular}{|c|c|c|c|c|}
\hline $\begin{array}{c}\mathrm{T} \\
\text { (weeks) }\end{array}$ & $\begin{array}{c}\text { Average Annual } \\
\text { Transp. Cost } \\
\text { (euros) }\end{array}$ & $\begin{array}{c}\text { Average Annual } \\
\text { Holding Cost } \\
\text { (euros) }\end{array}$ & $\begin{array}{c}\text { Average Annual } \\
\text { Tot. Cost } \\
\text { (euros) }\end{array}$ & $\begin{array}{c}\text { Average } \\
\% \text { Out of } \\
\text { Stock }\end{array}$ \\
\hline \multicolumn{5}{|c|}{ Experiment \# $1^{*}:\{7,8\} \mathrm{kj}=1 ;\{2,5\} \mathrm{kj}=2 ;\{1,3\} \mathrm{kj}=3 ;\{4,6\} \mathrm{kj}=4 ;$ All AddQj=0 } \\
\hline \multirow[t]{2}{*}{14} & 4,567 & 31,710 & 36,277 & 8.8 \\
\hline & $(185)^{*}$ & $(247)$ & $(354)$ & $(0.3)$ \\
\hline \multicolumn{5}{|c|}{ Experiment \# 2: $\{7,8\} \mathrm{kj}=1 ;\{2,5\} \mathrm{kj}=2 ;\{1,3\} \mathrm{kj}=2 ;\{4,6\} \mathrm{kj}=3 ;$ All AddQj=0 } \\
\hline \multirow[t]{2}{*}{18} & 3,593 & 19,618 & 23,211 & 9.4 \\
\hline & $(229)$ & $(236)$ & $(406)$ & $(1.9)$ \\
\hline \multicolumn{5}{|c|}{ Experiment \# 3: $\{7,8\} \mathrm{kj}=1 ;\{2,5\} \mathrm{kj}=1 ;\{1,3\} \mathrm{kj}=2 ;\{4,6\} \mathrm{kj}=3$ AddQj=500 } \\
\hline \multirow[t]{2}{*}{18} & 4,088 & 31,424 & 35,512 & 6.0 \\
\hline & $(178)$ & $(417)$ & $(520)$ & $(2.3)$ \\
\hline \multicolumn{5}{|c|}{ Experiment \# 4: $\{7,8\} \mathrm{kj}=1 ;\{2,5\} \mathrm{kj}=1 ;\{1,3\} \mathrm{kj}=1 ;\{4,6\} \mathrm{kj}=2 ;$ All AddQj=0 } \\
\hline \multirow[t]{2}{*}{24} & 3,120 & 23,033 & 26,153 & 8.9 \\
\hline & $(228)$ & $(359)$ & $(489)$ & $(1.6)$ \\
\hline \multicolumn{5}{|c|}{ Experiment \# 5: $\{7,8\} \mathrm{kj}=2 ;\{2,5\} \mathrm{kj}=3 ;\{1,3\} \mathrm{kj}=3 ;\{4,6\} \mathrm{kj}=4$ AddQj=1,000 } \\
\hline \multirow[t]{2}{*}{10} & 4,668 & 24,466 & 29,135 & 5.8 \\
\hline & $(260)$ & $(297)$ & $(409)$ & $(1.6)$ \\
\hline \multicolumn{5}{|c|}{ Experiment \# 6: $\{7,8\} \mathrm{kj}=2 ;\{2,5\} \mathrm{kj}=2 ;\{1,3\} \mathrm{kj}=3 ;\{4,6\} \mathrm{kj}=4$ AddQj=1,000 } \\
\hline \multirow[t]{2}{*}{12} & 3,661 & 20,242 & 23,903 & 6.1 \\
\hline & $(143)$ & $(296)$ & $(310)$ & (1.4) \\
\hline
\end{tabular}

\begin{tabular}{|c|c|c|c|c|c|c|c|c|c|c|}
\hline \multicolumn{11}{|c|}{ Total cost and \% out of stock for the experiments } \\
\hline$T$ & 10 & & & 12 & & 14 & & 18 & & 24 \\
\hline Exp. 1 & 73,282 & $(1.8 \%)$ & 49,378 & $(4.6 \%)$ & 36,277 & $(8.8 \%)$ & 20,485 & $(17.5 \%)$ & - & \\
\hline Exp. 2 & 90,415 & $(0.9 \%)$ & 62,651 & $(2.1 \%)$ & 42,962 & $(3.4 \%)$ & 23,211 & $(9.4 \%)$ & 12,447 & $(27.5 \%)$ \\
\hline Exp. 3 & 126,725 & $(0.3 \%)$ & 89,974 & $(1.1 \%)$ & 65,652 & $(1.9 \%)$ & 35,512 & $(6.0 \%)$ & 15,042 & $(19.5 \%)$ \\
\hline Exp. 4 & 173,052 & $(1.8 \%)$ & 131,717 & $(1.3 \%)$ & 98,704 & $(1.6 \%)$ & 55,132 & (3.0\%) & 26,153 & (8.9\%) \\
\hline Exp. 5 & 29,135 & (5.8\%) & 20,429 & $(12.0 \%)$ & 16,346 & $(17.6 \%)$ & 12,179 & $(25.2 \%)$ & - & \\
\hline Exp. 6 & 36,604 & (3.6\%) & 23,903 & $(6.1 \%)$ & 17,402 & $(14.9 \%)$ & 13,012 & $(26.1 \%)$ & - & \\
\hline
\end{tabular}

*) The numbers in parenthesis are the standard deviations of the average values. 


\section{Summary of simulation results}

Table 2. Experiments with one type of container

\begin{tabular}{|c|c|c|c|c|}
\hline $\begin{array}{c}\mathrm{T} \\
\text { (weeks) }\end{array}$ & $\begin{array}{l}\text { Average Annual } \\
\text { Transp. Cost } \\
\text { (euros) }\end{array}$ & $\begin{array}{l}\text { Average Annual } \\
\text { Holding Cost } \\
\text { (euros) }\end{array}$ & $\begin{array}{l}\text { Average Annual } \\
\text { Total Cost } \\
\text { (euros) }\end{array}$ & $\begin{array}{l}\text { Average } \\
\text { \% Out of } \\
\text { Stock }\end{array}$ \\
\hline FC1 & \multicolumn{4}{|c|}{$\begin{array}{l}\text { Two subsets of } 4 \text { chips with } \mathrm{kj}=2 \text { for all chips and additional chip in each } \\
\text { replenishment with frequency factor } \mathrm{pj}=8:\{1,2,3,4, \mathrm{Xpj}\},\{5,6,7,8, \mathrm{Xpj}\} \text {. }\end{array}$} \\
\hline 16 & $\begin{array}{l}2,222 \\
(135)^{*}\end{array}$ & $\begin{array}{c}36,028 \\
(120)\end{array}$ & $\begin{array}{c}38,251 \\
(189)\end{array}$ & $\begin{array}{c}7.6 \\
(0.9)\end{array}$ \\
\hline FC2 & \multicolumn{4}{|c|}{$\begin{array}{l}\text { Two subsets with chips } 7 \text { and } 8 \text { (higher demand) with } \mathrm{kj}=1 \text { and the } \\
\text { remaining chips with } \mathrm{kj}=2:\{7,8,1,2,4\},\{7,8,3,5,6\} \text {. }\end{array}$} \\
\hline 16 & $\begin{array}{l}2,222 \\
(134)\end{array}$ & $\begin{array}{c}33,307 \\
(260)\end{array}$ & $\begin{array}{c}35,529 \\
(312)\end{array}$ & $\begin{array}{c}7.2 \\
(1.0)\end{array}$ \\
\hline FC3 & \multicolumn{4}{|c|}{$\begin{array}{l}\text { Two subsets of } 4 \text { chips with } \mathrm{kj}=2 \text { for all chips and } 10,000 \text { additional items } \\
\text { in the replenishment (the additional items are distributed among the families } \\
\text { according to relative average demand): }\{1,2,3,4\}+10000,\{5,6,7,8\}+10000 \text {. }\end{array}$} \\
\hline 16 & $\begin{array}{l}2,222 \\
(112)\end{array}$ & $\begin{array}{c}31,666 \\
(187)\end{array}$ & $\begin{array}{c}33,889 \\
(254)\end{array}$ & $\begin{array}{c}7.2 \\
(0.7)\end{array}$ \\
\hline FC4 & \multicolumn{4}{|c|}{$\begin{array}{l}\text { Two subsets of } 3 \text { chips with } \mathrm{kj}=3 \text { and } 20,000 \text { additional items in the replenishment } \\
\text { (same consideration as in FC1.3), and one subset of } 2 \text { chips with } k j=3 \text { and } 30,000 \\
\text { additional items: }\{1,2,4\}+20000,\{3,5,6\}+20000,\{7,8\}+30000 \text {. }\end{array}$} \\
\hline 16 & 2,222 & $34,365 \quad(205$ & 36,587 & $\begin{array}{l}7.8 \\
(0.6)\end{array}$ \\
\hline LFC40 & \multicolumn{4}{|c|}{$\begin{array}{l}\text { LFC with } 40,000 \text { items. } \\
\text { Two subsets of } 4 \text { chips with } \mathrm{kj}=2:\{1,2,3,5\},\{4,6,7,8\} \text {. }\end{array}$} \\
\hline 14 & $\begin{array}{l}5,265 \\
(126)\end{array}$ & $\begin{array}{r}24,87 i \\
(142\end{array}$ & $\begin{array}{r}30,13 \\
(183\end{array}$ & $\begin{array}{c}7.7 \\
(0.8)\end{array}$ \\
\hline LFC30 & \multicolumn{4}{|c|}{$\begin{array}{l}\text { LFC with } 30,000 \text { items. } \\
\text { Two subsets of } 3 \text { chips each with } \mathrm{kj}=3 \text { and one subset of } 2 \text { chips with } \mathrm{kj}=3 \text { and } \\
10,000 \text { additional items in the replenishment: }\{1,2,4\},\{3,5,6\},\{7,8\}+10000 \text {. }\end{array}$} \\
\hline 10 & 5,844 & 27,794 & $\begin{array}{r}33,63 \\
(398\end{array}$ & $\begin{array}{c}5.7 \\
(0.6)\end{array}$ \\
\hline LFC20 & \multicolumn{4}{|c|}{$\begin{array}{l}\text { LFC with } 20,000 \text { items. } \\
\text { Four subsets of } 2 \text { chips each with } \mathrm{kj}=4:\{1,2\},\{3,4\},\{5,6\},\{7,8\} \text {. }\end{array}$} \\
\hline 6 & $\begin{array}{l}7,434 \\
(114)^{\star}\end{array}$ & $\begin{array}{c}37,753 \\
(157)\end{array}$ & $\begin{array}{c}45,188 \\
(377)\end{array}$ & $\begin{array}{c}4.2 \\
(0.4)\end{array}$ \\
\hline LFC10 & \multicolumn{4}{|c|}{$\begin{array}{l}\text { LFC with } 10,000 \text { items. } \\
8 \text { subsets of } 1 \text { chip each with } \mathrm{kj}=8:\{1\},\{2\},\{3\},\{4\},\{5\},\{6\},\{7\},\{8\} \text {. }\end{array}$} \\
\hline 4 & $\begin{array}{l}7,188 \\
(191)\end{array}$ & $\begin{array}{c}20,567 \\
(108)\end{array}$ & $\begin{array}{c}27,755 \\
(291)\end{array}$ & $\begin{array}{l}12.8 \\
(1.4)\end{array}$ \\
\hline
\end{tabular}

$\left.{ }^{*}\right)$ The numbers in parenthesis are the standard deviations of the average values. 
Sumary of simulation results

Table 3. Experiments with different size of container

\begin{tabular}{|c|c|c|c|c|}
\hline $\begin{array}{c}\mathrm{T} \\
\text { (weeks) }\end{array}$ & $\begin{array}{l}\text { Average Annual } \\
\text { Transp. Cost } \\
\text { (euros) }\end{array}$ & $\begin{array}{l}\text { Average Annual } \\
\text { Holding Cost } \\
\text { (euros) }\end{array}$ & $\begin{array}{l}\text { Average Annual } \\
\text { Total Cost } \\
\text { (euros) }\end{array}$ & $\begin{array}{c}\text { Average } \\
\% \text { Out of } \\
\text { Stock } \\
\end{array}$ \\
\hline (FC50+LFC30) & \multicolumn{4}{|c|}{$\begin{array}{l}\text { Full container and one LFC with } 30,000 \text { items. One subset containing } \\
\text { all chips with } \mathrm{kj}=1:\{1,2,3,4,5,6,7,8\} \text {. }\end{array}$} \\
\hline 26 & $\begin{array}{l}3,354 \\
(129)^{*}\end{array}$ & $\begin{array}{c}30,776 \\
(266)\end{array}$ & $\begin{array}{c}34,130 \\
(387)\end{array}$ & $\begin{array}{c}9.3 \\
(0.8)\end{array}$ \\
\hline (FC50,LFC30,LFC30) & \multicolumn{4}{|c|}{$\begin{array}{l}\text { Full container and two LFC with } 30,000 \text { alternately. Chips } 1,2,3,5,7 \text { and } \\
8 \text { with } \mathrm{kj}=2 \text { and chips } 4,6 \text { with } \mathrm{kj}=3 \text {, to get the following sequence of } \\
\text { replenishments: } \\
\{4,6,5,7,8\},\{1,2,3\},\{5,7,8\},\{4,6,1,2,3\},\{5,7,8\},\{1,2,3\},\{4,6,5,7,8\}, \ldots\end{array}$} \\
\hline 14 & $\begin{array}{l}3,684 \\
(162) \\
\end{array}$ & $\begin{array}{c}20,351 \\
(237) \\
\end{array}$ & $\begin{array}{c}24,034 \\
(364) \\
\end{array}$ & $\begin{array}{r}8.3 \\
(1.4) \\
\end{array}$ \\
\hline (FC50,LFC30) & \multicolumn{4}{|c|}{$\begin{array}{l}\text { Full container and one LFC with } 30,000 \text { alternately. One subset with } \\
5 \text { chips and one subset with } 3 \text { chips and all } k j=2:\{1,2,3,4,5\},\{6,7,8\} \text {. }\end{array}$} \\
\hline 14 & $\begin{array}{l}3,354 \\
(149) \\
\end{array}$ & $\begin{array}{c}27,839 \\
(369)\end{array}$ & $\begin{array}{c}31,193 \\
(470)\end{array}$ & $\begin{array}{c}9.6 \\
(1.2) \\
\end{array}$ \\
\hline (LFC30,LFC30,LFC20) & \multicolumn{4}{|c|}{$\begin{array}{l}\text { Two LFC with } 30,000 \text { items and one LFC with } 20,000 \text {, alternately. } \\
\text { Two subsets with } 3 \text { chips and one subset with two chips and all } k j=3 \text { : } \\
\{2,4,7\},\{3,6,8\},\{1,5\} \text {. }\end{array}$} \\
\hline 10 & $\begin{array}{l}5,390 \\
(198) \\
\end{array}$ & $\begin{array}{c}20,693 \\
(155)\end{array}$ & $\begin{array}{c}26,083 \\
(267)\end{array}$ & $\begin{array}{c}8.4 \\
(1.6) \\
\end{array}$ \\
\hline (FC50,LFC30,LFC45) & $\begin{array}{l}\text { Full container, LFC w } \\
\text { for chips } 4,5 \text { and } 6 \text {, a } \\
\{4,6,7,8\}+10000,\{1,2 \\
\{4,6,7,8\}+10000,\{1,2\end{array}$ & $\begin{array}{l}30,000 \text { and LFC } w \\
\mathrm{kj}=2 \text { for chips } 1,2 \\
\{5,7,8\}+15000,\{1 \\
\{5,7,8\}+15000,\{1\end{array}$ & $\begin{array}{l}\text { th } 45,000 \text {, alternate } \\
3,7 \text { and } 8 \text { to get the } \\
2,3,4,6\},\{7,8\}+1000 \\
2,3,4,6\}, \ldots\end{array}$ & $\begin{array}{l}\text { Set } k j=3 \\
\text { quence: } \\
1,2,3,5\}+5000\end{array}$ \\
\hline 16 & $\begin{array}{l}2,697 \\
(233)\end{array}$ & $\begin{array}{c}20,638 \\
(374)\end{array}$ & $\begin{array}{c}23,335 \\
(499)\end{array}$ & $\begin{array}{c}9.7 \\
(1.4)\end{array}$ \\
\hline
\end{tabular}

*) The numbers in parenthesis are the standard deviations of the average values. 
Summary of simulation results

Table 4. Experiments for the system with no minimum order quantities

a) $(T, S)$ Policy

$$
S=D(T+L)+z \sigma \sqrt{T+L}
$$

MOQ_Container $=10,000$ items, lead time $(L)=6$ weeks

\begin{tabular}{|c|c|c|c|c|c|c|c|}
\hline $\begin{array}{c}\text { Cycle } \\
\text { Service } \\
\text { Level (\%) }\end{array}$ & $\begin{array}{c}\text { Average Annual } \\
\text { Transp. Cost } \\
\text { (euros) } \\
\end{array}$ & $\begin{array}{c}\text { Average Annual } \\
\text { Holding Cost } \\
\text { (euros) }\end{array}$ & $\begin{array}{c}\text { Average Annual } \\
\text { Tot. Cost } \\
\text { (euros) }\end{array}$ & $\begin{array}{c}\text { Average } \\
\% \text { Out of } \\
\text { Stock } \\
\end{array}$ & $\begin{array}{c}\text { Average } \\
\text { TRS }\end{array}$ & $\begin{array}{l}\text { Average \# } \\
\text { of chips/year }\end{array}$ & $\begin{array}{l}\text { Average } \\
\text { of FC/yez }\end{array}$ \\
\hline \multicolumn{8}{|l|}{$T=1$} \\
\hline 99.87 & $\begin{array}{c}6,318 \\
(240)^{*}\end{array}$ & $\begin{array}{r}5,248 \\
(68)\end{array}$ & $\begin{array}{r}11,566 \\
(298)\end{array}$ & $\begin{array}{c}10.6 \\
(1.5)\end{array}$ & $\begin{array}{r}11,450 \\
(136)\end{array}$ & 25,000 & 0 \\
\hline 99.93 & $\begin{array}{r}6,591 \\
(139)\end{array}$ & $\begin{array}{r}5,479 \\
(88)\end{array}$ & $\begin{array}{r}12,070 \\
(207)\end{array}$ & $\begin{array}{l}8.6 \\
(1.0)\end{array}$ & $\begin{array}{r}11,303 \\
(118)\end{array}$ & " & 0 \\
\hline \multicolumn{8}{|l|}{$T=2$} \\
\hline 99.53 & $\begin{array}{r}5,958 \\
(158) \\
\end{array}$ & $\begin{array}{r}5,450 \\
(46) \\
\end{array}$ & $\begin{array}{r}11,409 \\
(195) \\
\end{array}$ & $\begin{array}{r}11.7 \\
(1.0) \\
\end{array}$ & $\begin{array}{r}12,539 \\
(154) \\
\end{array}$ & " & 0 \\
\hline 99.74 & $\begin{array}{r}6,369 \\
(182) \\
\end{array}$ & $\begin{array}{r}5,792 \\
(120) \\
\end{array}$ & $\begin{array}{r}12,161 \\
(257) \\
\end{array}$ & $\begin{array}{l}8.9 \\
(1.3) \\
\end{array}$ & $\begin{array}{r}12,415 \\
(310)\end{array}$ & $"$ & 0 \\
\hline \multicolumn{8}{|l|}{$T=4$} \\
\hline 98.61 & $\begin{array}{r}, 975 \\
(177) \\
\end{array}$ & $\begin{array}{r}6,285 \\
(85) \\
\end{array}$ & $\begin{array}{r}12,260 \\
(212)\end{array}$ & $\begin{array}{r}11.7 \\
(1.4) \\
\end{array}$ & $\begin{array}{r}15,060 \\
(682) \\
\end{array}$ & 25,000 & 0 \\
\hline 99.18 & $\begin{array}{r}6,374 \\
(282) \\
\end{array}$ & $\begin{array}{r}6,773 \\
\quad(192) \\
\end{array}$ & $\begin{array}{r}\mathbf{1 3 , 1 4 7} \\
(359) \\
\end{array}$ & $\begin{array}{l}8.0 \\
(2.2)\end{array}$ & $\begin{array}{r}14,371 \\
(571)\end{array}$ & $"$ & 0 \\
\hline \multicolumn{8}{|l|}{$T=6$} \\
\hline 94.52 & $\begin{array}{r}6,357 \\
\quad(425) \\
\end{array}$ & $\begin{array}{r}7,636 \\
(355) \\
\end{array}$ & $\begin{array}{r}13,993 \\
(570)\end{array}$ & $\begin{array}{l}9.2 \\
(3.5) \\
\end{array}$ & $\begin{array}{r}16,888 \\
(613) \\
\end{array}$ & 35,000 & 0 \\
\hline 96.41 & $\begin{array}{r}6,281 \\
(479) \\
\end{array}$ & $\begin{array}{r}7,824 \\
\quad(431) \\
\end{array}$ & $\begin{array}{r}14,105 \\
(704)\end{array}$ & $\begin{array}{l}7.3 \\
(3.4)\end{array}$ & $\begin{array}{r}17,540 \\
(785) \\
\end{array}$ & " & 0 \\
\hline \multicolumn{8}{|l|}{$T=8$} \\
\hline 94.52 & $\begin{array}{r}5,481 \\
(435) \\
\end{array}$ & $\begin{array}{r}8,617 \\
(472) \\
\end{array}$ & $\begin{array}{r}14,098 \\
(758)\end{array}$ & $\begin{array}{r}10.1 \\
(4.1) \\
\end{array}$ & $\begin{array}{r}22,991 \\
(1504) \\
\end{array}$ & $"$ & 0 \\
\hline 96.41 & $\begin{array}{r}5,807 \\
(138) \\
\end{array}$ & $\begin{array}{r}9,337 \\
(242) \\
\end{array}$ & $\begin{array}{r}15,144 \\
(368) \\
\end{array}$ & $\begin{array}{c}5.3 \\
(1.6) \\
\end{array}$ & $\begin{array}{r}22,384 \\
(621) \\
\end{array}$ & $"$ & 0 \\
\hline \multicolumn{8}{|l|}{$T=10$} \\
\hline 88.49 & $\begin{array}{r}5,361 \\
\quad(146) \\
\end{array}$ & $\begin{array}{r}9,806 \\
(230) \\
\end{array}$ & $\begin{array}{r}15,168 \\
(368) \\
\end{array}$ & $\begin{array}{l}8.7 \\
(2.2) \\
\end{array}$ & $\begin{array}{r}26,687 \\
(303) \\
\end{array}$ & 50,000 & 0 \\
\hline 91.92 & $\begin{array}{r}5,459 \\
(111) \\
\end{array}$ & $\begin{array}{r}10,282 \\
(223) \\
\end{array}$ & $\begin{array}{r}15,741 \\
(328) \\
\end{array}$ & $\begin{array}{l}6.3 \\
(1.8) \\
\end{array}$ & $\begin{array}{r}27,252 \\
(475) \\
\end{array}$ & $"$ & 0 \\
\hline \multicolumn{8}{|l|}{$\mathrm{T}=12$} \\
\hline 88.94 & $\begin{array}{r}5,070 \\
(70) \\
\end{array}$ & $\begin{array}{r}10,704 \\
(142) \\
\end{array}$ & $\begin{array}{r}\mathbf{1 5 , 7 7 4} \\
(169) \\
\end{array}$ & $\begin{array}{l}8.2 \\
(0.8)\end{array}$ & $\begin{array}{r}1,909 \\
(353) \\
\end{array}$ & 50,000 & 0.2 \\
\hline 91.92 & $\begin{array}{r}5,115 \\
(66) \\
\end{array}$ & $\begin{array}{r}11,239 \\
(197) \\
\end{array}$ & $\begin{array}{r}16,354 \\
(156) \\
\end{array}$ & $\begin{array}{l}6.3 \\
(0.8) \\
\end{array}$ & $\begin{array}{r}32,761 \\
(342) \\
\end{array}$ & $"$ & 0.2 \\
\hline $\mathrm{T}=14$ & & & & & & & \\
\hline 84.13 & $\begin{array}{r}4,756 \\
(150) \\
\end{array}$ & $\begin{array}{r}11,865 \\
(169) \\
\end{array}$ & $\begin{array}{r}\mathbf{1 6 , 6 2 1} \\
(242) \\
\end{array}$ & $\begin{array}{l}9.9 \\
(0.8)\end{array}$ & $\begin{array}{r}36,813 \\
(330) \\
\end{array}$ & 60,000 & 0.2 \\
\hline 88.49 & $\begin{array}{r}4,853 \\
(122) \\
\end{array}$ & $\begin{array}{r}12,234 \\
(123) \\
\end{array}$ & $\begin{array}{r}17,087 \\
(90) \\
\end{array}$ & $\begin{array}{l}8.3 \\
(0.6) \\
\end{array}$ & $\begin{array}{r}37,801 \\
(385) \\
\end{array}$ & $"$ & 0.2 \\
\hline
\end{tabular}

*) The numbers in parenthesis are the standard deviations of the average values. 
Table 4. Cont.

b) $(T, S, S)$ Policy

$M O Q \_C o n t a i n e r=10,000$ items, lead time $(L)=6$ weeks

\begin{tabular}{|c|c|c|c|c|c|c|c|}
\hline $\begin{array}{c}\text { Cycle } \\
\text { Service } \\
\text { Level (\%) }\end{array}$ & $\begin{array}{c}\text { Average Annual } \\
\text { Transp. Cost } \\
\text { (euros) }\end{array}$ & $\begin{array}{l}\text { Average Annual } \\
\text { Holding Cost } \\
\text { (euros) }\end{array}$ & $\begin{array}{l}\text { Average Annual } \\
\text { Tot. Cost } \\
\text { (euros) }\end{array}$ & $\begin{array}{c}\text { Average } \\
\% \text { Out of } \\
\text { Stock }\end{array}$ & $\begin{array}{l}\text { Average } \\
\text { TRS }\end{array}$ & $\begin{array}{c}\text { Average \# } \\
\text { of chips/year }\end{array}$ & $\begin{array}{l}\text { Average } \\
\text { of FC/yea }\end{array}$ \\
\hline \multicolumn{8}{|c|}{$\mathrm{T}=2, s=D L+z \sigma \sqrt{L}$} \\
\hline 99.74 & $\begin{array}{r}6,383 \\
(224)\end{array}$ & $\begin{array}{r}5,775 \\
(57)\end{array}$ & $\begin{array}{r}\mathbf{1 2 , 1 5 8} \\
(245)\end{array}$ & $\begin{array}{l}8.9 \\
(1.3)\end{array}$ & $\begin{array}{r}12,363 \\
(301)\end{array}$ & 25,000 & 0 \\
\hline 99.87 & $\begin{array}{r}6,531 \\
(192) \\
\end{array}$ & $\begin{array}{r}6,026 \\
(137) \\
\end{array}$ & $\begin{array}{r}12,557 \\
(313) \\
\end{array}$ & $\begin{array}{l}7.9 \\
(1.2) \\
\end{array}$ & $\begin{array}{r}12,420 \\
(210) \\
\end{array}$ & 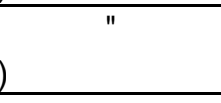 & 0 \\
\hline \multicolumn{8}{|l|}{$T=2, S=.8 S$} \\
\hline 99.74 & $\begin{array}{r}6,425 \\
(229)\end{array}$ & $\begin{array}{l}5,763 \\
(154)\end{array}$ & $\begin{array}{r}\mathbf{1 2 , 1 8 8} \\
(367)\end{array}$ & $\begin{array}{l}8.8 \\
(1.7)\end{array}$ & $\begin{array}{r}12,290 \\
(307)\end{array}$ & 25,000 & 0 \\
\hline 99.87 & $\begin{array}{r}6,572 \\
(161) \\
\end{array}$ & $\begin{array}{r}6,038 \\
(125) \\
\end{array}$ & $\begin{array}{r}12,610 \\
(251) \\
\end{array}$ & $\begin{array}{l}7.5 \\
(1.0)\end{array}$ & $\begin{array}{r}12,508 \\
(370) \\
\end{array}$ & 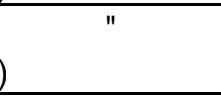 & 0 \\
\hline \multicolumn{8}{|l|}{$\mathrm{T}=2, \mathrm{~S}=.7 \mathrm{~S}$} \\
\hline 99.87 & $\begin{array}{r}6,277 \\
(212)\end{array}$ & $\begin{array}{r}5,876 \\
(127) \\
\end{array}$ & $\begin{array}{r}\mathbf{1 2 , 1 5 3} \\
(324)\end{array}$ & $\begin{array}{r}10.0 \\
(1.5)\end{array}$ & $\begin{array}{r}13,404 \\
(385)\end{array}$ & 25,000 & 0 \\
\hline 99.93 & $\begin{array}{r}, 434 \\
(87)\end{array}$ & $\begin{array}{r}6,155 \\
(93)\end{array}$ & $\begin{array}{r}12,589 \\
\quad(1390\end{array}$ & $\begin{array}{l}8.1 \\
(1.0)\end{array}$ & $\begin{array}{r}13,903 \\
(417)\end{array}$ & $"$ & 0 \\
\hline \multicolumn{8}{|l|}{$T=4, s$} \\
\hline 99.74 & $\begin{array}{r}5,702 \\
(110) \\
\end{array}$ & $\begin{array}{r}6,686 \\
(140) \\
\end{array}$ & $\begin{array}{r}12,388 \\
(232) \\
\end{array}$ & $\begin{array}{l}9.4 \\
(1.1)\end{array}$ & $\begin{array}{r}19,011 \\
(674) \\
\end{array}$ & 30,000 & 0 \\
\hline 99.87 & $\begin{array}{r}5,757 \\
(63) \\
\end{array}$ & $\begin{array}{r}6,981 \\
(173) \\
\end{array}$ & $\begin{array}{r}\mathbf{1 2 , 7 3 8} \\
(227) \\
\end{array}$ & $\begin{array}{l}7.7 \\
(1.40 \\
\end{array}$ & $\begin{array}{r}19,716 \\
(659) \\
\end{array}$ & $"$ & 0 \\
\hline \multicolumn{8}{|l|}{$\mathrm{T}=4, \mathrm{~S}=.8 \mathrm{~S}$} \\
\hline 99.18 & $\begin{array}{l}6,156 \\
(216)\end{array}$ & $\begin{array}{r}6,684 \\
(188)\end{array}$ & $\begin{array}{r}12,840 \\
(403)\end{array}$ & $\begin{array}{l}9.1 \\
(1.8)\end{array}$ & $\begin{array}{r}15,262 \\
(622)\end{array}$ & 25,000 & 0 \\
\hline 99.53 & $\begin{array}{r}6,466 \\
(350)\end{array}$ & $\begin{array}{r}7,122 \\
(220) \\
\end{array}$ & $\begin{array}{r}13,588 \\
(552)\end{array}$ & $\begin{array}{l}7.0 \\
(1.2)\end{array}$ & $\begin{array}{r}14,471 \\
(1086) \\
\end{array}$ & $"$ & 0 \\
\hline \multicolumn{8}{|l|}{$\mathrm{T}=4, \mathrm{~s}=.7 \mathrm{~S}$} \\
\hline 99.74 & $\begin{array}{r}5,899 \\
(88) \\
\end{array}$ & $\begin{array}{r}7,221 \\
(120) \\
\end{array}$ & $\begin{array}{r}13,120 \\
(196) \\
\end{array}$ & $\begin{array}{l}9.1 \\
(0.9)\end{array}$ & $\begin{array}{r}17,716 \\
(343) \\
\end{array}$ & 30,000 & 0 \\
\hline 99.87 & $\begin{array}{r}5,885 \\
(123) \\
\end{array}$ & $\begin{array}{r}7,454 \\
(100) \\
\end{array}$ & $\begin{array}{r}13,339 \\
(194)\end{array}$ & $\begin{array}{l}8.0 \\
(1.0)\end{array}$ & $\begin{array}{r}18,231 \\
(426) \\
\end{array}$ & 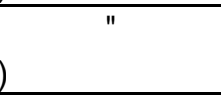 & 0 \\
\hline \multicolumn{8}{|l|}{$T=6, s$} \\
\hline 99.87 & $\begin{array}{r}5,364 \\
(359)\end{array}$ & $\begin{array}{r}8,417 \\
(80)\end{array}$ & $\begin{array}{r}\mathbf{1 3 , 7 8 1} \\
(364) \\
\end{array}$ & $\begin{array}{l}9.5 \\
(0.4)\end{array}$ & $\begin{array}{r}23,294 \\
(469) \\
\end{array}$ & 30,000 & 0 \\
\hline 99.93 & $\begin{array}{c}5,275 \\
(306)\end{array}$ & $\begin{array}{r}8,683 \\
(182)\end{array}$ & $\begin{array}{r}13,958 \\
(471)\end{array}$ & $\begin{array}{l}8.4 \\
(1.1)\end{array}$ & $\begin{array}{r}25,710 \\
(764)\end{array}$ & $"$ & \\
\hline \multicolumn{8}{|l|}{$\mathrm{T}=6, \mathrm{~s}=.8 \mathrm{~S}$} \\
\hline 94.52 & $\begin{array}{l}6,172 \\
(268)\end{array}$ & $\begin{array}{l}6,959 \\
(274)\end{array}$ & $\begin{array}{r}\mathbf{1 3 , 1 3 1} \\
(532)\end{array}$ & $\begin{array}{l}8.7 \\
(2.5)\end{array}$ & $\begin{array}{c}16,730 \\
(725)\end{array}$ & 30,000 & 0 \\
\hline 96.41 & $\begin{array}{r}6,517 \\
(100)\end{array}$ & $\begin{array}{r}7,576 \\
(149)\end{array}$ & $\begin{array}{r}14,093 \\
(239)\end{array}$ & $\begin{array}{l}5.5 \\
(0.96)\end{array}$ & $\begin{array}{r}16,631 \\
(241)\end{array}$ & $"$ & 0 \\
\hline
\end{tabular}


We use the average \% time out of stock at the DC as an indirect measure of the fill rate to measure customer service level, rather than using the fill rate itself, because we do not model demands at the DC. Following the algorithm presented in the last section we defined the six experiments showed in Table 1, starting out with experiment 1 in which we selected the initial values for the $k_{i}$ and then we try to improve them by using different subsets of the frequencies as defined by experiments 2 through 6.

The best strategy was found setting $k_{j}=1$ for chips $\{7,8\}, k_{j}=2$ for chips $\{1,2,3,5\}$ and $k_{j}=3$ for chips $\{4,6\}$ and $T=18$ weeks, with total associated average costs of 23,211 euros and average ready rate of $9.4 \%$. This policy produces a replenishment strategy in which a combination of full containers and different sizes of LFC are sent alternately. In this way we exploit the advantages of sending full containers. On the other hand, the use of LFC allows more flexibility to better control the inventory levels of items according to their rate of demand.

Case 1 (b). Experiments with predetermined size of container (Tables 2 and 3)

The experiments that used only one size of container resulted in very high annual costs, mainly because of the high holding costs involved. By using different sizes of container we can produce better strategies. The best one found was in experiment (FC50, LFC30, LFC45) with associated average costs of 23,335 euros and average ready rate of $9.7 \%$ (see Table 3), slightly worse than in case 1(a). This strategy allows to closely match the supply of items with the differences in average demand of the families by balancing better the amount of items sent in each shipment.

\section{Case 2. Experiments using $(T, S)$ and $(T, s, S)$ policies (Table 4)}

For both control policies $(T, S)$ and $(T, s, S)$ we vary the control parameters and evaluate for each case the following:

- Average total cost of the system per year = Average annual transportation cost + Average annual holding cost of items + Average annual holding cost of chips

- Average $\%$ time out of stock over all items ${ }^{2}$

- Average total replenishment size (TRS)

- Average number of chips held in stock

- Average number of full containers used per year

For all the experiments we set a maximum allowable average \% time out of stock of $10 \%$ at the DC, which is in accordance with the customer service level needed for the system. We run the simulation for 5 years.

For the $(T, S)$ policy we found that the best performance of the system is achieved with low values of the review time $T$. Although in this case the transportation costs are

\footnotetext{
${ }^{2}$ Although in equation (3) we implicitly use the probability of no stock out in each replenishment cycle as a measure of service level, during the simulation we rather look at the fraction of time during which the net stock is zero. We do this because of ease of evaluation and to be in accordance with the type of customer service measure defined for the case study and also used in case 1.
} 
relatively high because of frequent delivery of LFC's, the use of such values for $T$ allow us to keep the holding costs low, which are of greater impact in this case. We can see that the use of such a policy outperforms any possible strategy when the minimum order quantities are present. This is explained by the fact that the relaxation of the minimum order quantities let us have a better control of the individual inventories of items according to the differences in the demand patterns of the product. From the experiments we obtained that for about the same level of customer service level we save approximately $70 \%$ in holding costs by keeping the stock of chips and using a $(T, S)$ policy rather than the policies considered in case 1 . For $T=1$ and a value of $z=3.2$, the use of this policy resulted in average total costs of 12,070 euros with average ready rate of $8.6 \%$, much lower than the corresponding values for case 1.

If we use a reorder point strategy, i.e., a $(T, s, S)$ policy, the performance of the system is very close to that of the $(T, S)$ policy as we can see from the results. The best performance was found using $T=2$ and a reorder level $s$ equal to average demand over the lead time plus the safety stock, with associated average costs of 12,158 euros and average ready rate of $8.9 \%$. Recall that when using a reorder point we cannot order unless any of the items belonging to a family is below its reorder point. In such a case we lose the opportunity of trigger orders until the next replenishment epoch, in which some of the items in the system are already out of stock, and this explains why the best performance of the system is found under low values of the review time, although the effect of low holding cost is also important as in the $(T, S)$ case (Table 4).

\section{Some considerations using the EOQ method.}

Assuming a deterministic demand and a constant set-up cost, we perform some calculations using the EOQ procedure to investigate the behavior of the system when using a full container under minimum order quantities. Accordingly, consider the following data from the case study:

Total average demand of the system: $\mathrm{D}=2,942$ items/week

Set-up cost for an order: $A=700$ euros (for a full container)

Annual holding rate at the DC: $\mathrm{h}=25 \%$

Unit cost: $\mathrm{c}=1.25$ euros

and apply the EOQ formula to evaluate the optimal replenishment size ( 1 year $=52$ weeks):

$E O Q=\sqrt{\frac{2 A D}{h c}}=26,180 \quad$ items per replenishment

with associated holding and transportation costs:

$\sqrt{2 A D h c}=8,180$ euros, which are slightly higher than the corresponding average costs obtained for the $(T, S)$ or $(T, S, S)$ policies showed in table 4 . 
From the previous calculations we can see that the EOQ formula gives a lot size that does not meet the required size of a full container. If we further assume 4 to 5 chips in the replenishment, we can also see that imposing minimum order quantities tends to increase the lot size and consequently the average stock of items at the DC.

\section{Conclusions}

For a real supply chain we showed that in the presence of minimum order quantities for the items to be included in the replenishments, we can achieve coordination of orders and at the same time exploit the economies of scale of a transportation system with non-linear cost structure. Particularly, we found that a $\left(k_{j}, T\right)$ policy performs better than focusing directly on a specific container size. The $\left(k_{j}, T\right)$ method does have a varying order size. For this policy we showed that minimum order quantities can be incorporated in a JRP by a manual enumeration method even with complex transportation costs.

We considered the use of intermediate stocks of chips to relax the minimum order quantities and we showed that this action facilitates a better control of the supply chain because of shorter lead times and more effective inventory strategies. Particularly, we successfully apply a $(T, S)$ and a $(T, S, S)$ inventory policy with savings up to $44 \%$ in total costs.

We can generalize the conclusions found for our product to other similar supply chains for which we have a competitive product that is differentiated in families according to specific characteristics of the subassemblies. Today many items are produced in Asia because of low labor costs and then sent to Europe or US by sea in large quantities.

\section{References}

[1] D. Atkins, P.O. Iyogun, Periodic versus 'can-order' policies for coordinated multiitem inventory systems, Management Science 34 (1988), 791-796.

[2] J.L. Balintfy, On a basic class of multi-items inventory problems, Management Science 10 (1964), 287-297.

[3] A. Eynan, D.H. Kropp, Periodic review and joint replenishment in stochastic demand environments, IIE Transactions 30 (1998), 1025-1033.

[4] S.K. Goyal, Determination of optimum packaging frequency of items jointly replenished, Management Science 21 (1974), 436-443.

[5] E. Ignall, Optimal continuous review policies for two product inventory systems with joint setup costs, Management Science 15 (1969) 278-283. 
[6] C.B. Ramirez, A.J. Espinosa, Evaluation of a (R,s,Q,c) multi-item inventory replenishment policy through simulation, in Proceedings of the 1997 Winter Simulation Conference ed. S. Andradóttir, K.J. Healy, D.H. Withers, and B.L. Nelson.

[7] E.A. Silver, A control system for coordinated inventory replenishment, International Journal of Production Research, 12 (6) (1974), 647-671.

[8] E.A. Silver, A simple method of determining order quantities in joint replenishments under deterministic demand, Management Science 22 (1976), 13511361.

[9] E.A. Silver, D.F. Pyke, R. Peterson. Inventory Management and Production Planning and Scheduling. $3^{\text {rd }}$ Ed. (1998), New York: John Wiley \& Sons.

[10] S. Viswanathan, R. Piplani, Coordinating supply chain inventories through common replenishment epochs, European Journal of Operational Research 129 (2001), 277-286.

[11] R.E. Wildeman, J.B.G. Frenk, R. Dekker, An efficient optimal solution method for the joint replenishment problem, European Journal of Operational Research 99 (1997), 433-444. 